\title{
Lactic acid bacteria used as preservative in fresh feed for marine shrimp maturation
}

\author{
Genyess Ribeiro Arthur da Silva Vieira(1), Mariana Soares ${ }^{(1)}$, Norha Constanza Bolívar Ramírez ${ }^{(1)}$, \\ Delano Dias Schleder ${ }^{(2)}$, Bruno Corrêa da Silva( ${ }^{(3)}$, José Luiz Pedreira Mouriño(1), \\ Edemar Roberto Andreatta ${ }^{(1)}$ and Felipe do Nascimento Vieira ${ }^{(1)}$
}

\begin{abstract}
(1)Universidade Federal de Santa Catarina, Centro de Ciências Agrárias, Departamento de Aquicultura, Laboratório de Camarões Marinhos, Rodovia Admar Gonzaga, no 1.346, CEP 88034-000 Florianópolis, SC, Brazil. E-mail: genyess.vieira@gmail.com, marisoares23@hotmail.com, norhabolivar@yahoo.com, jose.mourino@ufsc.br, edemar.andreatta@ufsc.br, felipe.vieira@ufsc.br (2)Instituto Federal Catarinense, Núcleo de Pesquisa em Pesca e Aquicultura, Campus Araquari, Rodovia BR-280, Km 27, CEP 89245-000 Araquari, SC, Brazil. E-mail: delano.schleder@ifc-araquari.edu.br ${ }^{(3)}$ Empresa de Pesquisa Agropecuária e Extensão Rural de Santa Catarina, Centro de Desenvolvimento em Aquicultura e Pesca, Rodovia Antonio Heil, no 6.800, CEP 88318-112 Itajaí, SC, Brazil. E-mail: bcorrea85@gmail.com
\end{abstract}

Abstract - The objective of this work was to evaluate the effect of Lactobacillus plantarum on the preservation of fresh mussels and its effect on the attractiveness, consumption, and midgut bacterial microbiota of Pacific white shrimp broodstock. The experiment evaluated mussels stored with $L$. plantarum at $4^{\circ} \mathrm{C}$. The controls were: mussels stored at $-18^{\circ} \mathrm{C}$ without $L$. plantarum; mussels stored at $-18^{\circ} \mathrm{C}$ with $L$. plantarum; and mussels stored at $4^{\circ} \mathrm{C}$ without $L$. plantarum. Microbiological analyses on mussels were performed on days $1,7,15$, 30,45 , and 60 after processing. Additionally, mussels preserved with L. plantarum and stored at $4^{\circ} \mathrm{C}$, and mussels stored at $-18^{\circ} \mathrm{C}$ without $L$. plantarum were evaluated after 15 days for attractiveness, consumption, and midgut bacterial microbiota of shrimps. Mussels preserved with L. plantarum showed higher lactic acid bacteria counts and lower counts of Vibrio spp., as well as of total heterotrophic bacteria, after 60 days of storage. No differences were observed for attractiveness or consumption between treatments. The bacterial microbiota of midgut in shrimp fed mussels preserved with $L$. plantarum showed higher lactic acid bacteria count and lower Vibrio spp. The use of L. plantarum inhibits Vibrio spp. and preserves feed without changing attractiveness or consumption for shrimp.

Index terms: Lactobacillus plantarum, Litopenaeus vannamei, Vibrio, probiotic.

\section{Bactérias ácido-lácticas como conservantes do alimento fresco para a maturação de camarões marinhos}

Resumo - O objetivo deste trabalho foi avaliar o efeito de Lactobacillus plantarum sobre a conservação de mexilhões frescos e avaliar a atratividade, o consumo e a microbiota intestinal de reprodutores de camarão-branco-do-pacífico. O experimento avaliou mexilhões estocados com L. plantarum a $4^{\circ} \mathrm{C}$. Os controles foram: mexilhões estocados a $-18^{\circ} \mathrm{C}$ sem $L$. plantarum; mexilhões estocados a $-18^{\circ} \mathrm{C}$ com L. plantarum; e mexilhões estocados a $4^{\circ} \mathrm{C}$ sem L. plantarum. As análises microbiológicas dos mexilhões foram realizadas nos dias 1, 7, 15, 30, 45 e 60 após o processamento. Além disso, os mexilhões conservados com L. plantarum e estocados a $4^{\circ} \mathrm{C}$ e os mexilhões estocados a $-18^{\circ} \mathrm{C}$ sem L. plantarum, após 15 dias, foram avaliados quanto à atratividade, ao consumo e à microbiota bacteriana intestinal dos camarões. Mexilhões conservados com L. plantarum tiveram maiores contagens de bactérias ácido-lácticas e menores contagens de Vibrio spp., assim como de bactérias heterotróficas totais, após 60 dias de estocagem. Não foram observadas diferenças significativas quanto à atratividade ou ao consumo entre os tratamentos. A microbiota intestinal dos camarões alimentados com mexilhões conservados com L. plantarum apresentou maior contagem de bactérias ácido-lácticas e menor contagem de Vibrio spp. O uso de L. plantarum inibe Vibrio spp. e conserva o alimento, sem modificar a atratividade ou o consumo pelos camarões.

Termos para indexação: Lactobacillus plantarum, Litopenaeus vannamei, Vibrio, probiótico.

\section{Introduction}

Marine shrimp farming stands out as one of the most important sectors in aquaculture. In particular,
Litopenaeus vannamei, was responsible for $80 \%$ of world shrimp production in 2014 (FAO, 2016). The reproduction of L. vannamei in captivity is well established; however, an incomplete or unbalanced 
diet can cause poor reproductive performance, or even hinder breeding (Peixoto et al., 2011). Until now, no commercial feed that meets all reproductive needs has been available. Consequently, the use of fresh feed, such as mussels, squid, fish roe and artemia biomass, is essential (Kolkovisk \& Kolkovisk, 2011).

In the maturation sector, fresh feed is commonly stored at $-18^{\circ} \mathrm{C}$ (Hoa et al., 2009). However, freezing forms ice crystals which can cause tissue damage. This process results in exudation, fluid loss, reduced nutritional value, and changes in the texture and appearance of feed after defrosting (Cordeiro et al., 2007). Freezing can also affect the structural and chemical properties of meat, such as muscle fibers, lipids and proteins (Pietrasik \& Janz, 2009).

An alternative for the preservation of fresh feed is the use of lactic acid bacteria. These bacteria can control the spread of pathogenic ones of the Vibrio genus, which are commonly found in squid and mussels (Prado et al., 2010). Lactic acid bacteria could also help in the prevention of viral contamination as that caused by White Spot Syndrome Virus (WSSV), which is sensitive to low pH (Gao et al., 2011). As final products, lactic acid bacteria generate lactic acid and other organic acids, hydrogen peroxide, and bacteriocins, which act as biopreservatives controlling the dissemination of various microbes and pathogenic bacteria. For these reasons, lactic acid bacteria have been used in the preservation of different raw foods, such as meat, milk, and vegetables (Fadda et al., 2010; Udhayashree et al., 2012; Newaj-Fyzul et al., 2014).

In addition, using lactic acid bacteria as a feed preservative can have probiotic effects. Several studies have shown the probiotic benefits for marine shrimp by improving the balance of midgut microbiota (Vieira et al., 2008; Zhang et al., 2009), survival (Pham et al., 2014), resistance to infection (Chiu et al., 2007; Vieira et al., 2007), immunostimulation (Tseng et al., 2009; NavinChandran et al., 2014), and digestibility (Buglione-Neto et al., 2013).

The objective of this work was to evaluate the effect of Lactobacillus plantarum on the preservation of fresh mussels, and its effect on the attractiveness, consumption, and midgut bacterial microbiota of Pacific white shrimp broodstock.

\section{Materials and Methods}

The experiment was conducted from May to October 2012. The shrimp species used was Litopenaeus vannamei (Bonne, 1931) from a specific-pathogen-free (SPF) lineage Speedline SPF (Aquatec Aquacultura Ltda., Canguaretama, RN, Brazil). They were kept in biofloc system tanks $(50,000 \mathrm{~L})$ at the Laboratório de Camarões Marinhos (LCM), Universidade Federal de Santa Catarina (UFSC). Fresh mussels (Perna perna, Linnaeus, 1978) were obtained from the Laboratório de Moluscos Marinhos (LMM/UFSC).

The lactic acid bacterium strain Lactobacillus plantarum (CPQBA 00707 DRM01) was used as a probiotic. This bacterium was isolated from adult L. vannamei shrimp (Vieira et al., 2007) and maintained in the Microbiology Laboratory of the LMC/UFSC at $-20^{\circ} \mathrm{C}$, in MRS culture medium (De Man et al., 1960) supplemented with $25 \%$ glycerol (Ramírez et al., 2006).

The preservation trial evaluated the mussel preserved with $L$. plantarum stored at $4^{\circ} \mathrm{C}$. The following controls were used: a standard method for shrimp broodstock by which mussels were stored at $-18^{\circ} \mathrm{C}$, without L. plantarum; freezing control by which mussels were preserved with L. plantarum and stored at $-18^{\circ} \mathrm{C}$; and a bacterial control by which mussels were stored at $4^{\circ} \mathrm{C}$, without L. plantarum.

At first, an inoculum of $L$. plantarum was prepared by growing the bacterium in MRS liquid medium supplemented with $3 \% \mathrm{NaCl}$, for 24 hours at $35^{\circ} \mathrm{C}$, until reaching a concentration of $10^{9}$ colony forming units (CFU) per milliliter (Vieira et al., 2008). Then, $500 \mathrm{~g}$ of fresh mussels were stored in $500 \mathrm{~mL}$ glass bottles and, then, they were immersed in L. plantarum inoculum suspension $\left(10^{9} \mathrm{UFC} \mathrm{mL}^{-1}\right)$ for 6 hours at room temperature $\left(28^{\circ} \mathrm{C}\right)$. Next, excess of the inoculum suspension was removed by sieving ( $1 \mathrm{~mm}$ mesh) during $5 \mathrm{~min}$, and mussels were packed in 50 plastic vacuum-sealed bags containing $10 \mathrm{~g}$ mussels each. One half of the bags was stored at $4^{\circ} \mathrm{C}$, and the other half was frozen at $-18^{\circ} \mathrm{C}$. Similarly, $500 \mathrm{~g}$ of mussels were placed in 50 plastic bags with $10 \mathrm{~g}$ each, without inoculum and, then, they were vacuum packed and stored under two different conditions: $4^{\circ} \mathrm{C}$ and $-18^{\circ} \mathrm{C}$.

Microbiological analyses of mussels were performed on days $1,7,15,30,45$, and 60 , after processing (all in triplicate). To perform the analysis, $1 \mathrm{~g}$ from each sample was removed, macerated in a mortar, and 10 -fold serially diluted up to $10^{-8}$ dilution in sterile saline solution (SSE) at $3 \% \mathrm{NaCl}$. The dilutions were cultured in the following media: Marine Agar medium (Difco, Leeuwarden, The Netherlands) for total count of

Pesq. agropec. bras., Brasília, v.51, n.11, p.1799-1805, nov. 2016 DOI: 10.1590/S0100-204X2016001100001 
heterotrophic bacteria; Thiosulfate Citrate Bile Sucrose agar - TCBS (Difco), for total count of Vibrio spp.; and MRS Agar, for count of lactic acid bacteria. Colony forming units (CFU) were determined 24 hours after incubation at $30^{\circ} \mathrm{C}$ in Marine Agar and TCBS agar, and 48 hours after incubation at $35^{\circ} \mathrm{C}$ in MRS.

Based on the preservation trial, mussels preserved with $L$. plantarum and stored at $4^{\circ} \mathrm{C}$, and mussels stored at $-18^{\circ} \mathrm{C}$, both during 15 days, were evaluated for attractiveness, consumption, and midgut bacterial microbiota of shrimp.

Attractiveness was evaluated according to Nunes et al. (2006). In the present work, we used a Y-shaped glass aquarium equipped with a Y-maze $1.3 \times 0.3 \times$ $0.4 \mathrm{~m}$ (length $\mathrm{x}$ width $\mathrm{x}$ height). Shrimp $(24 \pm 1.47 \mathrm{~g})$ used for attractiveness analysis were kept in a $6 \mathrm{Mg}$ tank with 30-35\%o salinity, at $28-29^{\circ} \mathrm{C}$, above $5 \mathrm{mg} \mathrm{L}^{-1}$ dissolved oxygen, and 7.5-8.0 pH. To stimulate faster feeding response, shrimp were left to fast 24 hours prior to analysis. Shrimp behavior was evaluated in three ways, as described by Nunes et al. (2006): detection time, orientation time/locomotion, and feeding activity. When the chosen diet was consumed, it was classified as a positive choice, and when it was refused, it was recorded as rejection. The number of positive choices was calculated as a percentage, to finally compare each diet. Before each behavioral assessment, aquarium water was changed to prevent the influence of contamination from the diet previously used, and shrimp were kept in a chamber for acclimatization for $10 \mathrm{~min}$ to allow adaptation to the system. Subsequently, the two experimental diets were offered separately in equal amounts of $2 \mathrm{~g}$, and placed individually on the perimeter of the arms of the Y-maze. Thirty-three tests were performed (one shrimp per test). Timeout was set at $7 \mathrm{~min}$; thus, in the case of nondetection, shrimp specimen was changed.

Mussel consumption test was conducted in six $50 \mathrm{~L}$ aquaria stocked with four shrimp each $(24 \pm 1.47 \mathrm{~g})$, using the two diets above described (in triplicate). Feeding was carried out twice a day, at 9 am and $3 \mathrm{pm}$, at $6 \%$ of shrimp biomass. After one hour, feed leftovers were collected and frozen at $-18^{\circ} \mathrm{C}$. Samples were collected for seven days. For dry weight determination, samples were placed in an oven at $105^{\circ} \mathrm{C}$ until constant weight was achieved, which required about 27 hours. Feed consumption was calculated by "ingestion of feed per hour", a formula described by Hernandez-Cortes et al. (1999) as L=Mi-Mf-Mp/T, in which: $\mathrm{L}$, is the ingestion of feed per hour; Mi, is the initial weight of dry feed; $\mathrm{Mf}$ is the final dry weight of feed; Mp is the weight of dry feed dissolved in water; and $\mathrm{T}$ is the elapsed time of feed in water.

After testing consumption, shrimp remained on their respective treatments until the $18^{\text {th }}$ day of feeding. Subsequently, 24 shrimp (12 of each treatment) were collected, disinfected with alcohol at $70 \%$, and their midguts were extirpated in a laminar flow chamber. The midguts were weighed, homogenized in a mortar, serially diluted in $3 \% \mathrm{NaCl} \mathrm{SSE}(1 / 10)$, and seeded in culture medium as described by Vieira et al. (2008).

The values of bacterial counts on mussels and shrimp midguts were transformed to $\log _{10}(\mathrm{x}+1)$ before analysis. Data were analyzed by the Bartlett test to verify homoscedasticity. Data were also subjected to analysis of variance with repeated measures supplemented by the Tukey's test. Meanwhile, data from mussel consumption and midgut microbiota were analyzed by Student's t test. For percentages of choice and rejection of feed, chi-square test was used, whereas detection time, locomotion, and feeding were all analyzed by Student's t test. All tests were performed at $5 \%$ probability.

\section{Results and Discussion}

Mussels preserved with L. plantarum, regardless of the storage temperature, had higher lactic acid bacterial counts. No difference was observed in the count of total heterotrophic bacteria for the different treatments until the $30^{\text {th }}$ day (Table 1). On day $60^{\text {th }}$, mussels preserved with L. plantarum and stored at both $4^{\circ} \mathrm{C}$ and $-18^{\circ} \mathrm{C}$ had lower total heterotrophic bacteria count than mussels without L. plantarum. For the count of Vibrio spp., mussels preserved with L. plantarum and stored at $-18^{\circ} \mathrm{C}$ showed lower values on the seventh day, in comparison to the other treatments; and, from the 15th day, mussels preserved with L. plantarum, at both temperatures, had lower counts of Vibrio spp. Lactic acid bacteria count in mussels preserved with L. plantarum indicates that these bacteria remained viable in the mussels. This group of bacteria is used as biopreservatives to improve sensory quality, color, and texture of feed by decreasing the feed $\mathrm{pH}$ and producing bacteriocins, organic acids, and hydrogen peroxide, which have bacteriostatic or bactericidal activity (Fadda et al., 2010). Reduced heterotrophic bacteria count in mussels preserved with $L$. plantarum

Pesq. agropec. bras., Brasília, v.51, n.11, p.1799-1805, nov. 2016 DOI: $10.1590 / \mathrm{S} 0100-204 X 2016001100001$ 
and stored at $-18^{\circ} \mathrm{C}$, and lower counts of Vibrio spp. in the mussels preserved with $L$. plantarum could be attributed to these substances (Fadda et al., 2010).

Souza et al. (2006) conducted a study on the antimicrobial activity of Lactobacillus sakei in fermented striped bonito (Euthynnus pelamis) showing the inhibitory effect of $L$. sakei strain against spoilage bacteria. Additionally, this strain caused an effective reduction of $\mathrm{pH}$ by the lactic acid production. The same results were observed by Espírito Santo et al. (2003), who utilized $L$. sakei in the fermentation process of Brazilian sardinella (Sardinella brasiliensis). These results support the hypothesis that low $\mathrm{pH}$ (3.8) combined with antimicrobial compounds generated by L. plantarum sufficiently preserved fresh mussels at both temperatures.

Using L. plantarum combined with storage at $4^{\circ} \mathrm{C}$ can be advantageous for shrimp reproduction in commercial laboratories, which have mainly used storage at $-18^{\circ} \mathrm{C}$ (Hoa et al., 2009). Since feed in this case does not undergo freezing, the formation of ice crystals can be prevented. As noted previously, this condition can cause tissue damage, and such damage, in turn, can result in exudation, loss of liquids, reduction of nutritional value, and change of the texture and appearance of feed (Cordeiro et al., 2007). Additionally, feed stored at $4^{\circ} \mathrm{C}$ reduces energy cost compared to that stored at $-18^{\circ} \mathrm{C}$.

The attractiveness and consumption tests showed no difference between the two offered diets, - that is, mussels preserved with L. plantarum and stored at $4^{\circ} \mathrm{C}$, and mussels stored at $-18^{\circ} \mathrm{C}$ without L. plantarum -, which suggests that $L$. vannamei had no preference for either diet (Table 2).

Lactic acid bacteria count on the midgut of shrimp fed mussels preserved with L. plantarum and stored

Table 1. Lactic acid bacteria, total heterotrophic bacteria and Vibrio spp. counts in mussels preserved with Lactobacillus plantarum and stored at $4^{\circ} \mathrm{C}\left(\right.$ L. plantarum $\left.+4^{\circ} \mathrm{C}\right)$, mussels stored at $4^{\circ} \mathrm{C}$ without L. plantarum (control $\left.+4^{\circ} \mathrm{C}\right)$, mussels frozen at $-18^{\circ} \mathrm{C}$ without $L$. plantarum (control $-18^{\circ} \mathrm{C}$ ), and mussels preserved with $L$. plantarum and stored at $-18^{\circ} \mathrm{C}(L$. plantarum $-18^{\circ} \mathrm{C}$ ) for 60 days ${ }^{(1)}$.

\begin{tabular}{|c|c|c|c|c|c|c|}
\hline \multirow[t]{2}{*}{ Treatment } & \multicolumn{6}{|c|}{ Days of analysis } \\
\hline & 1 & 7 & 15 & 30 & 45 & 60 \\
\hline & \multicolumn{6}{|c|}{ Count of lactic acid bacteria in agar MRS $\left(\log \mathrm{CFU} \mathrm{g}{ }^{-1}\right)$} \\
\hline L. plantarum $+4^{\circ} \mathrm{C}$ & $8,08 \pm 0,21 \mathrm{a}$ & $8,09 \pm 0,15 \mathrm{a}$ & $7,94 \pm 0,03 \mathrm{a}$ & $7,43 \pm 0,38 \mathrm{a}$ & $7,29 \pm 0,49 \mathrm{a}$ & $6,62 \pm 0,33 b$ \\
\hline Control $+4^{\circ} \mathrm{C}$ & $3,72 \pm 0,12 b$ & $2,39 \pm 0,09 b$ & $2,74 \pm 0,26 b$ & $3,19 \pm 0,59 b$ & $2,39 \pm 0,09 c$ & $3,15 \pm 1,93 \mathrm{a}$ \\
\hline L. plantarum $-18^{\circ} \mathrm{C}$ & $4,66 \pm 0,26 b$ & $7,76 \pm 0,28 \mathrm{a}$ & $7,76 \pm 0,28 \mathrm{a}$ & $7,80 \pm 0,76 \mathrm{a}$ & $7,40 \pm 0,17 \mathrm{a}$ & $6,87 \pm 0,15 b$ \\
\hline \multirow[t]{2}{*}{ Control $-18^{\circ} \mathrm{C}$} & $2,15 \pm 0,15 \mathrm{c}$ & $2,15 \pm 0,15 b$ & $0,00 \pm 0,00 \mathrm{c}$ & $3,40 \pm 0,35 b$ & $4,35 \pm 0,17 \mathrm{~b}$ & $3,08 \pm 0,46 a$ \\
\hline & \multicolumn{6}{|c|}{ Count of total heterotrophic bacteria in agar Marine $\left(\log C F U g^{-1}\right)$} \\
\hline L. plantarum $+4^{\circ} \mathrm{C}$ & $3,51 \pm 3,04 \mathrm{a}$ & $4,97 \pm 2,57 \mathrm{a}$ & $5,15 \pm 1,20 \mathrm{a}$ & $2,95 \pm 2,59 \mathrm{a}$ & $2,90 \pm 2,59 \mathrm{ab}$ & $4,43 \pm 1,50 \mathrm{bc}$ \\
\hline Control $+4^{\circ} \mathrm{C}$ & $6,79 \pm 3,08 \mathrm{a}$ & $7,05 \pm 2,42 \mathrm{a}$ & $5,76 \pm 0,11 \mathrm{a}$ & $5,68 \pm 3,38 \mathrm{a}$ & $5,70 \pm 3,39 a$ & $9,05 \pm 2,95 \mathrm{a}$ \\
\hline L. plantarum $-18^{\circ} \mathrm{C}$ & $4,33 \pm 1,84 a$ & $4,14 \pm 1,25 \mathrm{a}$ & $4,36 \pm 0,14 \mathrm{a}$ & $4,12 \pm 1,05 \mathrm{a}$ & $0,00 \pm 0,00 b$ & $0,00 \pm 0,00 \mathrm{c}$ \\
\hline \multirow[t]{2}{*}{ Control $-18^{\circ} \mathrm{C}$} & $2,86 \pm 0,42 \mathrm{a}$ & $5,95 \pm 2,88 \mathrm{a}$ & $5,32 \pm 0,17 \mathrm{a}$ & $4,81 \pm 3,44 a$ & $4,38 \pm 0,74 a$ & $8,46 \pm 1,89 \mathrm{ab}$ \\
\hline & \multicolumn{6}{|c|}{ Count of Vibrio spp. in agar TCBS $\left(\log\right.$ CFU g $\left.{ }^{-1}\right)$} \\
\hline L. plantarum $+4^{\circ} \mathrm{C}$ & $4,45 \pm 1,55 \mathrm{ab}$ & $2,38 \pm 0,43 a$ & $0,77 \pm 1,33 b$ & $0,00 \pm 0,00 \mathrm{c}$ & $0,00 \pm 0,00 \mathrm{~b}$ & $0,00 \pm 0,00 \mathrm{~b}$ \\
\hline Control $+4^{\circ} \mathrm{C}$ & $5,14 \pm 1,52 \mathrm{a}$ & $4,33 \pm 1,25 \mathrm{a}$ & $3,65 \pm 2,31 \mathrm{a}$ & $2,65 \pm 1,33 b$ & $2,30 \pm 1,91 \mathrm{a}$ & $2,30 \pm 1,91 \mathrm{a}$ \\
\hline L. plantarum $-18^{\circ} \mathrm{C}$ & $4,30 \pm 1,15 \mathrm{ab}$ & $0,00 \pm 0,00 b$ & $1,00 \pm 0,30 b$ & $0,00 \pm 0,00 \mathrm{c}$ & $0,00 \pm 0,00 b$ & $0,00 \pm 0,00 \mathrm{~b}$ \\
\hline Control $-18^{\circ} \mathrm{C}$ & $2,87 \pm 0,97 \mathrm{~b}$ & $3,56 \pm 1,45 \mathrm{a}$ & $4,63 \pm 2,17 \mathrm{a}$ & $5,34 \pm 1,57 a$ & $3,83 \pm 2,00 \mathrm{a}$ & $3,09 \pm 2,00 \mathrm{a}$ \\
\hline
\end{tabular}

${ }^{(1)}$ Means followed by equal letters, in the columns, do not differ by Tukey's test, at $5 \%$ probability.

Table 2. Percentages (\%) of positive choices, detection time, locomotion, and feeding activity, for Litopenaeus vannamei shrimp held in a Y-maze apparatus, and offered diets consisting of mussels preserved with Lactobacillus plantarum stored at $4^{\circ} \mathrm{C}\left(\right.$ L. plantarum $\left.+4^{\circ} \mathrm{C}\right)$, and mussels stored at $-18^{\circ} \mathrm{C}$ without L. plantarum (control $-18^{\circ} \mathrm{C}$ ).

\begin{tabular}{lccccc}
\hline Diet & $\begin{array}{c}\text { Consumption } \\
(\mathrm{g} \text { per shrimp) }\end{array}$ & $\begin{array}{c}\text { Detection time } \\
(\mathrm{s})\end{array}$ & $\begin{array}{c}\text { Locomotion } \\
(\mathrm{s})\end{array}$ & \multicolumn{2}{c}{ Feeding activity } \\
$(\mathrm{s})$ & $\begin{array}{c}\text { Positive choices } \\
(\%)\end{array}$ \\
\hline Control $-18^{\circ} \mathrm{C}$ & $0.69 \pm 0.19$ & $144.03 \pm 174.32$ & $338.05 \pm 267.60$ & $576.52 \pm 278.41$ & 57,57 \\
L.plantarum $+4{ }^{\circ} \mathrm{C}$ & $0.53 \pm 0.21$ & $82.78 \pm 55.21$ & $384.21 \pm 239.47$ & $551.64 \pm 243.85$ & 42,43 \\
\hline
\end{tabular}


at $4^{\circ} \mathrm{C}$ was higher than the count for the group fed mussels stored at $-18^{\circ} \mathrm{C}$ without L. plantarum (Figure 1). Vibrio spp. count was lower in the midgut of shrimp fed mussels on a diet of L. plantarum and stored at $4^{\circ} \mathrm{C}$. For total heterotrophic bacteria count, no difference was observed between groups.

The largest number of lactic acid bacteria was found in the midgut of shrimp fed mussels preserved with L. plantarum and stored at $4^{\circ} \mathrm{C}$, which indicates that $L$. plantarum remains viable in shrimp midgut. The same result was observed in L. vannamei fed ration supplemented with L. plantarum (Vieira et al., 2008; Ramírez et al., 2013). In addition, L. plantarum isolated from $L$. vannamei midgut has potential as a probiotic, inhibiting the growth of pathogenic bacteria, and enhancing the immunological system (Vieira et al., 2007, Vieira et al., 2013).

In addition, Vibrio spp. count was reduced in the guts of shrimp fed mussels on a diet of L. plantarum and stored at $4^{\circ} \mathrm{C}$, possibly by the ability of $L$. plantarum to produce antimicrobial substances (Deegan et al., 2006). Similar results were observed in L. vannamei fed ration supplemented with L. plantarum (Vieira et al., 2007, 2008; Ramírez et al., 2013). These studies show that $L$. plantarum has a probiotic activity, thus improving immune parameters and resistance to infection (Vibrio sp.) in marine shrimp. Therefore, the utilization of fresh mussels preserved with

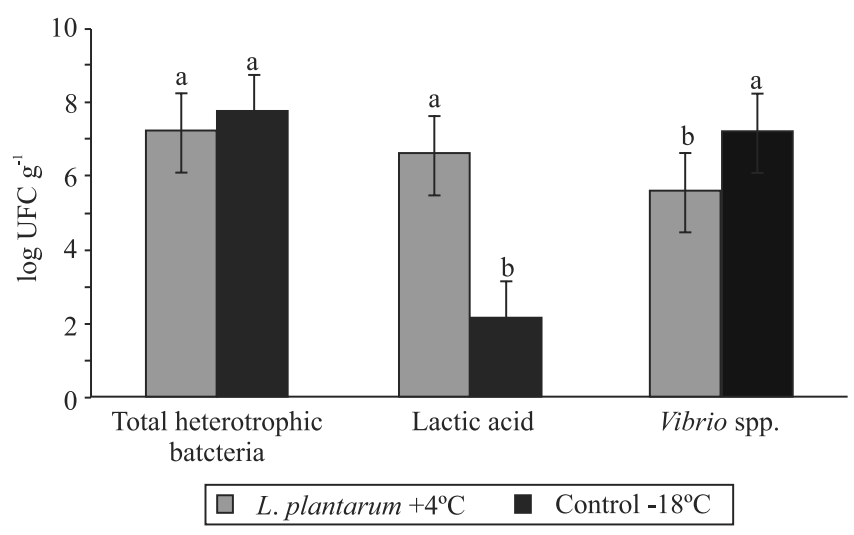

Figure 1. Count of total heterotrophic bacteria, lactic acid bacteria, and Vibrio spp., in the midgut of shrimp fed mussels preserved with Lactobacillus plantarum and stored at $4^{\circ} \mathrm{C}\left(\right.$ L. plantarum $\left.+4^{\circ} \mathrm{C}\right)$, and mussels stored at $-18^{\circ} \mathrm{C}$ (control $-18^{\circ} \mathrm{C}$ ). Different letters indicate differences between treatments, in the columns, by Student's t test, at $5 \%$ probability.
L. plantarum, in shrimp breeding laboratories, could be a promising alternative to frozen feed, since it can act as a biopreservative and as a probiotic for shrimp broodstock.

\section{Conclusions}

1. Fresh mussels can be preserved with the use of Lactobacillus plantarum, and they can be stored at $4^{\circ} \mathrm{C}$ for up to 60 days, without changing attractiveness and consumption by Litopenaeus vannamei broodstock.

2. L. plantarum modifies the midgut microbiota of L. vannamei shrimp fed mussels which consumed these bacteria; this fact increases the number of lactic acid bacteria and decreases Vibrio spp. in shrimp.

\section{Acknowledgements}

To Conselho Nacional de Desenvolvimento Científico e Tecnológico (CNPq, process numbers PQ 309868/2014-9 and 308292/2014-6), for fellowships granted; to Ministério da Pesca e Aquicultura (MPA), for financial support; to the Southern Oceans Education \& Development Project (SOED), for the scholarship granted; and to Dr. Aimê Rachel Magenta Magalhães of the Laboratório de Moluscos Marinhos (LMM/ USFC), for supplying mussels for the experiment.

\section{References}

BUGLIONE-NETO,C.;MOURIÑO,J.L.;VIEIRA,F.doN.;SILVA, B.C. da; JATOBÁ, A.; SEIFFERT, W.; FRACALOSSI, D.M.; ANDREATTA, E. Métodos para determinação da digestibilidade aparente de dietas para camarão marinho suplementadas com probiótico. Pesquisa Agropecuária Brasileira, v.48, p.1021-1027, 2013. DOI: 10.1590/S0100-204X2013000800030.

CHIU, C.-H.; GUU, Y.-K.; LIU, C.-H.; PAN, T.-M.; CHENG, $\mathrm{W}$. Immune responses and gene expression in white shrimp, Litopenaeus vannamei, induced by Lactobacillus plantarum. Fish and Shellfish Immunology, v.23, p.364-377, 2007. DOI: 10.1016/j.fsi.2006.11.010.

CORDEIRO, D.; LOPES, T.G.G.; OETTERER, M.; PORTO, E.; GALVÃO, J.A. Qualidade do mexilhão Perna perna submetido ao processo combinado de cocção, congelamento e armazenamento. Boletim do Centro de Pesquisa e Processamento de Alimentos, v.25, p.165-179, 2007. DOI: 10.5380/cep.v25i1.8404.

DE MAN, J.C.; ROGOSA, M.; SHARPE, M.E. A medium for the cultivation of Lactobacilli. Journal of Applied Microbiology, v.23, p.130-135, 1960.

DEEGAN, L.H.; COTTER, P.D.; HILL, C.; ROSS, P. Bacteriocins: biological tools for bio-preservation and shelf-life extension. 
International Dairy Journal, v.16, p.1058-1071, 2006. DOI: 10.1016/j.idairyj.2005.10.026.

ESPÍRITO SANTO, M.L.P.; BEIRÃO, L.H.; SANT'ANNA, E.S.; DALCIN, E.B.; FRANCO, B.G.M. Bacteriocinogenic effect of Lactobacillus sakei $2 \mathrm{a}$ on microbiological quality of fermented Sardinella brasiliensis. Brazilian Archives of Biology and Technology, v.46, p.553-561, 2003. DOI: 10.1590/ S1516-89132003000400009.

FADDA, S.; LÓPEZ, C.; VIGNOLO, G. Role of lactic acid bacteria during meat conditioning and fermentation: Peptides generated as sensorial and hygienic biomarkers. Meat Science, v.86, p.66-79, 2010. DOI: 10.1016/j.meatsci.2010.04.023.

FAO. Food and Agriculture Organization of United Nations. Producción acuícola mundial. Available at: <http://www.fao. org/figis/servlet/SQServlet?file=/work/FIGIS/prod/webapps/ figis/temp/hqp_1598805917840436372.xml\&outtype $=$ html $>$. Accessed on: May 262016.

GAO, H.; KONG, J.; LI, Z.; XIAO, G.; MENG, X. Quantitative analysis of temperature, salinity and $\mathrm{pH}$ on WSSV proliferation in Chinese shrimp Fenneropenaeus chinensis by real-time PCR. Aquaculture, v.312, p.26-31, 2011. DOI: 10.1016/j. aquaculture.2010.12.022.

HERNANDEZ-CORTES, P.; QUADROS SEIFFERT, W.; TORO, M.A.N. del; PORTILLO, G.; COLADO, G.; GARCIA-CARREÑO, F.L. Rate of ingestion and proteolytic activity in digestive system of juvenile white shrimp, Penaeus vannamei, during continual feeding. Journal of Applied Aquaculture, v.9, p.35-45, 1999. DOI: 10.1300/J028v09n01_03.

HOA, N.D.; WOUTERS, R.; WILLE, M.; THANH, V.; DONG, T.K.; HAO, N.V; SORGELOOS, P. A fresh-food maturation diet with an adequate HUFA composition for broodstock nutrition studies in black tiger shrimp Penaeus monodon (Fabricius, 1798). Aquaculture, v.297, p.116-121, 2009. DOI: 10.1016/j. aquaculture.2009.09.005.

KOLKOVISK, S.; KOLKOVISK, J. Maturation diets for shrimp - Is there alternative to natural food? International AquaFeed, v.14, p.14-15, 2011.

NAVINCHANDRAN, M.; IYAPPARAJ, P.; MOOVENDHAN, S.; RAMASUBBURAYAN, R.; PRAKASH, S.; IMMANUEL, G.; PALAVESAM, A. Influence of probiotic bacterium Bacillus cereus isolated from the gut of wild shrimp Penaeus monodon in turn as a potent growth promoter and immune enhancer in $P$. monodon. Fish and Shellfish Immunology, v.36, p.38-45, 2014. DOI: 10.1016/j.fsi.2013.10.004.

NEWAJ-FYZUL, A.; AL-HARBI, A.H.; AUSTIN, B. Review: Developments in the use of probiotics for disease control in aquaculture. Aquaculture, v.431, p.1-11, 2014. DOI: 10.1016/j. aquaculture.2013.08.026.

NUNES, A.J.P.; SÁ, M.V.C.; ANDRIOLA-NETO, F.F.; LEMOS, D. Behavioral response to selected feed attractants and stimulants in Pacific white shrimp, Litopenaeus vannamei. Aquaculture, v.260, p.244-254, 2006. DOI: 10.1016/j.aquaculture.2006.06.027.

PEIXOTO, S.; WASIELESKY, W.; CAVALLI, R.O. Broodstock maturation and reproduction of the indigenous pink shrimp Farfantepenaeus paulensis in Brazil: An updated review on research and development. Aquaculture, v.315, p.9-15, 2011. DOI: 10.1016/j.aquaculture.2010.04.009.

PHAM, D.; ANSQUER, D.; CHEVALIER, A.; DAUGA, C.; PEYRAMALE, A.; WABETE, N.; LABREUCHE, Y. Selection and characterization of potential probiotic bacteria for Litopenaeus stylirostris shrimp hatcheries in New Caledonia. Aquaculture, v.432, p.475-482, 2014. DOI: 10.1016/j.aquaculture.2014.04.031.

PIETRASIK, Z.; JANZ, J.A.M. Influence of freezing and thawing on the hydration characteristics, quality, and consumer acceptance of whole muscle beef injected with solutions of salt and phosphate. Meat Science, v.81, p.523-532, 2009. DOI: 10.1016/j. meatsci.2008.10.006.

PRADO, S.; ROMALDE, J.L.; BARJA, J.L. Review of probiotics for use in bivalve hatcheries. Veterinary Microbiology, v.145, p.187-197, 2010. DOI: 10.1016/j.vetmic.2010.08.021.

RAMÍREZ, C.; BOLÍVSR, G.; CIFONNI, E.; PANCHENIAK, E.F.R.; SOCCOL, C.R. Microrganismos lácticos con características probióticas para ser aplicados en la alimentación de larvas de camarón y peces como subs tituto de antibiótico. La Alimentación Latinoamericana, v.264, p.70-78, 2006.

RAMÍREZ, N.B.; SEIFFERT, W.Q.; VIEIRA, F. do N.; MOURIÑO, J.L.P.; JESUS, G.F.A.; FERREIRA, G.S.; ANDREATTA, R.E. Dieta suplementada com prebiótico, probiótico e simbiótico no cultivo de camarões marinhos. Pesquisa Agropecuária Brasileira, v.48, p.913-919, 2013. DOI: 10.1590/S0100-204X2013000800015.

SOUZA, J.; RODRIGUES, L.G.G.; GONZALEZ, P.N.M.; TORTATO, R.; CARBONEA, N.; ESPÍRITO SANTO, M.L.P. Atividade antimicrobiana do Lactobacillus sakei na fermentação do bonito-de-barriga-listrada (Euthynnus pelamis). Vetor, v.16, p.25-36, 2006.

TSENG, D.-Y.; HO, P.-L.; HUANG, S.-Y.; CHENG, S.-C.; SHIU, Y.-L.; CHIU, C.-S.; LIU, C.-H. Enhancement of immunity and disease resistance in the white shrimp, Litopenaeus vannamei, by the probiotic, Bacillus subtilis E20. Fish and Shellfish Immunology, v.26, p.339-344, 2009. DOI: 10.1016/j. fsi.2008.12.003.

UDHAYASHREE, N.; SENBAGAM, D.; SENTHILKUMAR, B.; NITHYA, K.; GURUSAMY, R. Production of bacteriocin and their application in food products. Asian Pacific Journal of Tropical Biomedicine, v.2, p.406-410, 2012. Supplement. DOI: 10.1016/S2221-1691(12)60197-X.

VIEIRA, F. do N.; BUGLIONE NETO, C.C.; MOURIÑO, J.L.P.; JATOBÁ, A.; RAMIREZ, C.; MARTINS, M.L.; BARRACCO, M.A.A.M.; VINATEA, L.A. Time-related action of Lactobacillus plantarum in the bacterial microbiota of shrimp digestive tract and its action as immunostimulant. Pesquisa Agropecuária Brasileira, v.43, p.763-769, 2008. DOI: 10.1590/ S0100-204X2008000600013.

VIEIRA, F. do N.; JATOBÁ, A.; MOURIÑO, J.L.P.; VIEIRA, E.A.; SOARES, M.; SILVA, B.C. da; SEIFFERT, W.Q.; MARTINS, M.L.; VINATEA, L.A. In vitro selection of bacteria with potential for use as probiotics in marine shrimp culture. Pesquisa Agropecuária Brasileira, v.48, p.998-1004, 2013. DOI: 10.1590/S0100-204X2013000800027. 
VIEIRA, F. do N.; PEDROTTI, F.S.; BUGLIONE NETO, C.C.; MOURIÑO, J.L.; BELTRAME, E.; MARTINS, M.L.; RAMIREZ, C.; ARANA, L.A.V. Lactic-acid bacteria increase the survival of marine shrimp, Litopenaeus vannamei, after infection with Vibrio harveyi. Brazilian Journal of Oceanography, v.55, p.251-255, 2007. DOI: 10.1590/ S1679-87592007000400002.
ZHANG, L.; MAI, K.; TAN, B.; AI, Q.; QI, C.; XU, W.; ZHANG, W.; LIUFU, Z.; WANG, X.; MA, H. Effects of dietary administration of probiotic Halomonas sp. B12 on the intestinal microflora, immunological parameters, and midgut histological structure of shrimp, Fenneropenaeus chinensis. Journal of the World Aquaculture Society, v.40, p.58-66, 2009. DOI: 10.1111/j. 1749-7345.2008.00235.x.

Received on September 29, 2015 and accepted on July 29, 2016 